\title{
Preface to the Issue Moral Competence \& Subjectivity: Topical Issues
}

\author{
Joanna Dutka \\ (Adam Mickiewicz University in Poznań, joanna.dutka7@gmail.com) \\ Karolina Napiwodzka \\ (Adam Mickiewicz University in Poznań, karolina.napiwodzka@amu.edu.pl)
}

We present an issue of Ethics in Progress entitled Moral Competence And Subjectivity: Topical Issues. Several papers in this volume were authored by the participants of the conference Moral Competence: A Brand New Research Topic in Cognitive Psychology, Ethics and Law, which took place on September 2017 at A. Mickiewicz University in Poznań, and was devoted to the Konstanz Method of Dilemma Discussion (KMDD $®$ ) developed by Prof. Georg Lind. Martina Reinicke presents research findings regarding the relation between teaching morality and developing the atmosphere of inclusion in school. Małgorzata Steć argues that the KMDD $®$ method and the Dual Aspect Theory of moral behavior correspond with the latest findings in neuropsychology. Shaogang Yang stresses the importance of embodied moral cognition and moral judgment in the light of recent developments in the neurocognitive sciences. Qian Zhang and Stephen J. Thoma present their research on the influence of gender, education, academic performance and the one-child policy on the moral judgment competence.

The inquiries into subjectivity cover a very wide spectrum of topics, starting from one of the latest and boldest questions in modern scholarship, and examined in this volume by André Schmiljun, namely: How to consider robots as moral patients (passive holders of moral rights) and moral agents? Yuan Guo presents studies that empirically confirm the relationship between social support, resilience and life satisfaction - support from family and friends helps an individual retain physical and mental health, contributing positively to the ability of individuals to fulfil responsibilities. Pawel Mazur considers subjectivity in the context of the disciplinary responsibility of judges in Polish legal system. Przemysław Górecki discusses how in the dichotomous gender system "masculinity" is a socially privileged category, assigned with ethical value, in contrast to "femininity" which is only associated with aesthetic values. This collection rounds off with a review of the book Spór o podmiotowośc Perspektywa Interdyscyplinarna (The Dispute About Subjectivity: An Interdisciplinary Perspective) by Adriana Warmbier, in which Karolina Napiwodzka provides an overview of modern research on the problem of subjectivity. 